$$
\begin{gathered}
\text { NAG } 2-100 \\
\text { IN-51-CR } \\
146707 \\
230 .
\end{gathered}
$$

\title{
Dexamethasone Regulates Glutamine Synthetase Expression in Rat Skeletal Muscles
}

STEPHEN R. MAX ${ }^{1}$, MASAAKI KONAGAYA ${ }^{1 *}$, YOKO KONAGAYA ${ }^{*}$, JOHN W. THOMAS ${ }^{2}$, CARL BANNER ${ }^{2}$ and LJUBIŠA VITKOVIĆ2

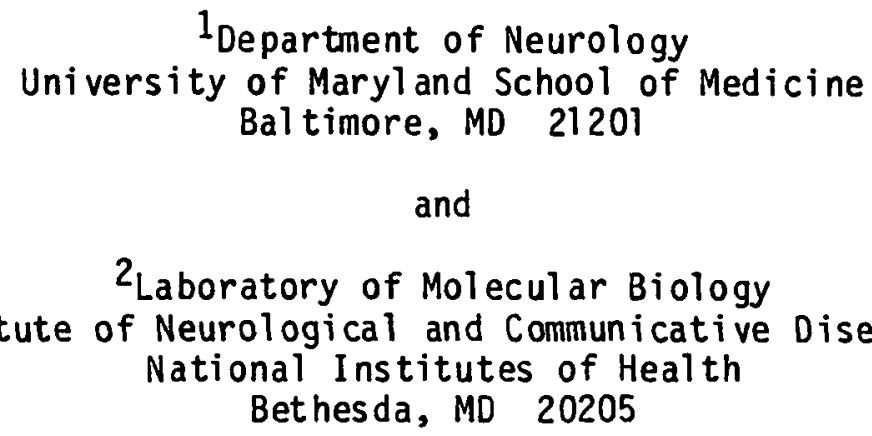

Short Title: Muscle Glutamine Synthetase

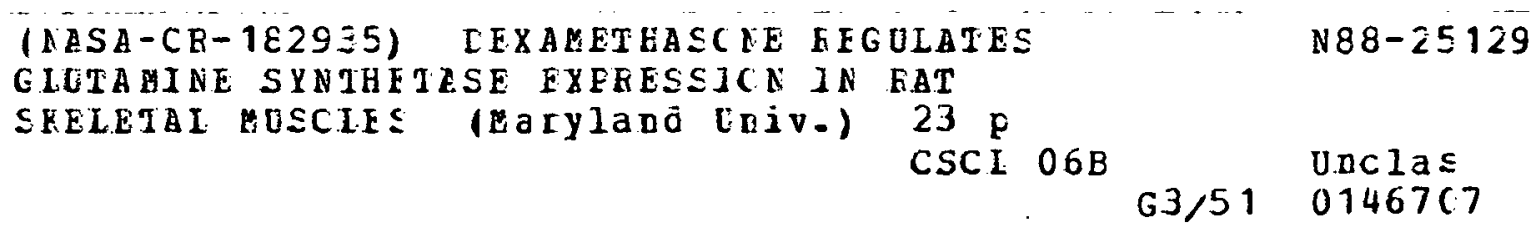

Send proofs to:

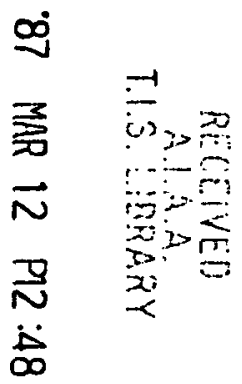

Stephen R. Max, Ph.D. Department of Neurology University of Maryl and

School of Medicine

Baltimore, MD 21201

(301) $528-3436$ 
ABSTRACT. We studied the regulation of glutamine synthetase by glucocorticoids in rat skeletal muscles. Administration of dexamethasone strikingly enhanced glutamine synthetase activity in plantaris and soleus muscles. The dexamethasone-mediated induction of glutamine synthetase activity was blocked to a significant extent by orally administered RU38486, a glucocorticoid antagonist, indicating the involvement of intracellular glucocorticoid receptors in the induction. Northern blot analysis revealed that dexamethasone-mediated enhancement of glutamine synthetase activity involves dramatically increased levels of glutamine synthetase mRNA. The induction of glutamine synthetase was selective in that glutaminase activity of soleus and plantaris muscles was not increased by dexamethasone. Furthermore, dexamethasone treatment resulted in only a small (15\%) increase in glutamine synthetase activity in heart. Accordingly, there was only a slight (if any) change in glutamine synthetase mRNA level in this tissue. Thus, glucocorticoids regulate glutamine synthetase gene expression in rat muscles at the transcriptional level via interaction with intracellular receptors. Such regulation may be relevant to control of glutamine production by muscle and to mechanisms underlying glucocorticoid-induced muscle atrophy. 
Glucocorticoids cause marked atrophy of skeletal muscle (14). This atrophy, which appears to involve intracellular glucocorticoid receptors (4), involves alterations in protein synthesis (2, 5-10) and, possibly, protein degradation (11-16). However, the molecular basis of glucocorticoid-mediated muscle atrophy is not understood. An important step toward understanding how glucocorticoids cause muscle atrophy is the study of genes that may be regulated to produce the catabolic response. Such a gene may be that for glutamine synthetase, the activity of which is enhanced in L6 muscle cells in vitro and in rat muscles in vivo following dexamethasone treatment (17-19). Skeletal muscle synthesizes and releases glutamine, which is a substrate for energy metabolism in a number of other tissues, including intestine, fibroblasts, and, possibly, brain (20 - review). Amino acids derived from degradation of muscle proteins (21) are the primary source of muscle glutamine; glutamine synthetase is the synthetic enzyme.

Recently, we demonstrated that dexamethasone caused a striking increase in the level of glutamine synthetase mRNA in L6 muscle cells in culture (19). However, an in vitro system is valuable only insofar as it reflects events in the intact organism. Therefore, we examined the effects of dexamethasone on rat skeletal muscles in vivo. A major objective was to evaluate the hypothesis that increased glutamine synthetase is involved in the catabolic actions of glucocorticoids on muscle (19).

In this report, we provide evidence that glutamine synthetase activity in rat muscles in vivo is increased by dexamethasone; 
that the increase results from enhanced production of glutamine synthetase mRNA; and, that induction of glutamine synthetase is mediated via intracellular glucocorticoid receptors. By contrast, dexamethasone exerted minimal effects on glutamine synthetase activity and mRNA level in heart.

\section{Materials and Methods}

\section{Materials}

Male rats $(\mathrm{crl}: \mathrm{CD}(S O) B R$ strain, Charles River Breeding Labs, Wilmington, Mass.) weighing 200-225 g were used. They were maintained on a schedule of $12 \mathrm{~h} 1 \mathrm{ight}$ and $12 \mathrm{~h}$ darkness, and they were fed Purina Rodent Laboratory Chow (no. 5001, Ralston Purina, St. Louis, MO) and water ad libitum. Dexamethasone was administered s.c. at a doses of $5 \mathrm{mg} / \mathrm{kg}$; RU38486 [11B-(4-

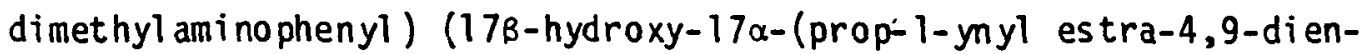
3-one)] was administered p.o. at $50 \mathrm{mg} / \mathrm{kg}$. The dexamethasone dose was selected because it is effective in eliciting muscle atrophy (e.g., 4). The dose of RU38486 was selected because of its ability to block muscle glucocorticoid receptors and glucocorticoid-mediated muscle atrophy in vivo (4). RU38486 was a gift of Roussel-UCLAF (Paris, France). L-glutamic acid-[U- $\left.{ }^{14} \mathrm{C}\right]$, specific activity 200-250 $\mathrm{mCi} / \mathrm{mmol}$, and L-glutamine-[U-14 C], specific activity $200-250 \mathrm{mCi} / \mathrm{mmol}$, were purchased from Research Products International (Mount Prospect, IN). The RNA probe vector PGEM-2, and the in vitro transcription system, Riboprobe, were from Promega Biotec (Madison, WI). All other chemicals were obtained from Sigma Chemical Co. (St. Louis, MI). 


\section{Enzyme Assays}

Glutamine synthetase and glutaminase activities were assayed using the method of Rowe (22) as described by 5 mith et al. (17), except that the glutamate concentration was $5 \mathrm{mM}$ in our glutamine synthetase assays. These assays separate product from substrate by ion-exchange chromatography. The substrates were glutamic acid $\left[U-{ }^{14} \mathrm{C}\right]$ and glutamine-[U-14 $\left.\mathrm{C}\right]$, for glutamine synthetase and glutaminase, respectively. Glutamine synthetase activity in rat muscles was completely inhibited by $10 \mu \mathrm{M}$ L-methionine sulfoximine, a specific inhibitor of this enzyme (22).

Protein

This was determined according to Lowry et al. (23), using crystalline bovine serum al bumin as standard.

mRNA (Northern Blot) Analysis

Soleus and plantaris muscles and heart were frozen and pulverized in liquid nitrogen in a mortar and pestle that had been treated with diethyl pyrocarbonate (24). The powders were stored at $-70^{\circ} \mathrm{C}$. Total cellular RNA was isolated from frozen powders of soleus, plantaris and heart muscles using the guanidine isothiocyanate procedure of Chirgwin et al. (25). RNA was fractionated by electrophoresis through agarose gels containing formaldehyde (26), transferred to nitrocellulose filters, and hybridized with a radioactive RNA probe by the method of Southern (27). The RNA probe was prepared by in vitro transcription (28) from an EcoRI/HindII fragment of the Chinese hamster glutamine synthetase gene (29) subcloned into PGEM-2, a pUC-12-derived plasmid containing both SP6 and T7 promoters (28). 
Statistical Analysis

This was performed using analysis of variance and Dunnett's mul tiple comparisons test (30) or Student's t-test (Table 1).

\section{Results and Discussion}

Dexamethasone caused a striking increase in glutamine synthetase activity in rat soleus and plantaris muscles. The time-course of the effect of dexamethasone on glutamine synthetase activity in rat soleus and plantaris muscles is shown in Fig. 1 . Glutamine synthetase activity in both muscles was 2 times the control values $24 \mathrm{~h}$ after dexamethasone administration and increased to about 6-fold greater than control after 7 daily injections of the steroid hormone.

Enhancement of glutamine synthetase activity by dexamethasone probably is mediated via interaction of the steroid hormone with intracellular glucocorticoid receptors, which are present in rat muscles $(4,31)$. This conclusion is based upon the data of Fig. 2, in which it is seen that RU38486, a potent and selective glucocorticoid antagonist in a number of tissues (32) including muscle (4), significantly reduced the dexamethasone-mediated increase in enzyme activity. Lack of complete inhibition of the dexamethasone effect by this 1 arge dose of RU38486, compared with complete blockade in vitro (19), may be due to a higher level of non-specific binding of RU38486 to plasma proteins (34). Administration of RU38486 by itself was without effect on glutamine synthetase activity (33). That the induction of glutamine synthetase is selective for glucocorticoids is shown further by the data of Fig. 4. Dexamethasone and triamcinolone 
acetonide caused major increases in glutamine synthetase. Progesterone caused a $50 \%$ increase in enzyme activity. Muscle is considered to be devoid of progestin receptors $(35,36)$. The effect of this steroid homone on glutamine synthetase, which we also observed in vitro (19), may be due to direct agonist action on glucocorticoid receptors in muscle. Such agonist action has been demonstrated in certain hepatoma cells (37). Estradiol was effective, albeit less so, than progesterone. Possibly, estrogen acted directly via estrogen receptors, which are known to exist in muscle (38). Testosterone was without effect.

Heart muscle glutamine synthetase increased by only $15 \%$ ( $p<$ 0.05) after 7 days of daily s.c. injections of dexamethasone at 5 $\mathrm{mg} / \mathrm{kg}$, in striking contrast to the large increases $(+500 \%)$ in enzyme activity in plantaris and soleus muscles (Fig. 4).

The dexamethasone-mediated increase in glutamine synthetase activity is at least partly a result of an increased level of glutamine synthetase mRNA. Northern blot analysis (Fig. 5) demonstrates that giutamine synthetase mRNA (a major band of $3 \mathrm{~kb}$ ) was increased dramatically in plantaris muscles from dexamethasone-treated rats compared with control animals. By contrast, there was a small, if any, change in glutamine synthetase mRNA level in heart. Thus, there is good correlation between enhanced glutamine synthetase activity and increased levels of glutamine synthetase mRNA (Figs. 5 and 6 ).

Exposure of autoradiograms for prolonged periods revealed a second smaller (ca. $1.5 \mathrm{~Kb}$ ) glutamine synthetase mRNA species, in agreement with Kumar et al. (39) and Bhandari et al. (40). 
Further work is needed to evaluate whether this smaller species also is regulated by dexamethasone and to confirm that it codes for glutamine synthetase.

Induction of glutamine synthetase precedes muscle atrophy and appears to be a common denominator in atrophy of a number of causes $(18,33,42)$. Therefore, we have hypothesized that glutamine synthetase may be involved in a fundamental manner in the process of atrophy.

It has been demonstrated that glucocorticoid hormones are anabolic in heart muscle, actually causing an increase in protein synthesis (41). The lack of induction of glutamine synthetase by dexamethasone in this tissue supports our hypothesis of a role for glutamine synthetase in glucocorticoid-mediated muscle atrophy (19). However, our hypothesis is not supported by the observation that glutamine synthetase activity is enhanced in soleus muscles from dexamethasone-treated rats (Figs. 2, 3). Soleus muscle is notoriously resistant to glucocorticoịd-mediated muscle atrophy (e.g., 4). Paradoxically, soleus muscle contains a high level of cytosolic glucocorticoid receptors (43). The difference in response to glucocorticoids may reflect the activity patterns of these muscles. Plantaris is a fast-twitch, fatiguable muscle that fires phasically; soleus is a slow-twitch, fatigue-resistant muscle that fires tonically (44). Perhaps the continuous activity of the soleus muscle protects it from wasting. Indeed, glucocorticoid-mediated muscle atrophy is reversed by physical activity (45). It is also possible that differences in rates of protein turnover between these muscles (46-50) may account for the 
disparity in hormonal responsiveness. Further experimentation will be necessary to evaluate these possibilities.

Glutaminase activity in rat muscles was not induced by dexamethasone treatment (Table I), indicating that the dexamethasone effect on glutamine synthetase is selective. In fact, dexamethasone caused a significant $30 \%$ decrease in glutaminase activity in soleus muscle (Table I). Whether this decrease is biologically significant is not known.

These data demonstrate that glutamine synthetase is induced by glucocorticoids in rat muscles; that this induction involves the activity of intracellular glucocorticoid receptors; and that it occurs, at least in part, at the transcriptional level. These observations agree with our data on L6 muscle cells in vitro (19). To our knowledge, glutamine synthetase appears to be the first glucocorticoid-induced protein to be identified in skeletal muscle. It should provide a valuable biochemical marker for further studies of glucocorticoid hormone-regulated gene expression in muscle. 


\section{Acknowl edgements}

We thank Dr. B.H. Sohmer for helpful comments, Ms. M.A. Wennes for technical assistance, and Ms. B. Pasko for preparation of the typescript. RU38486 was a generous gift of Dr. R. Deraedt, Roussel-UCLAF, Romainville, France. The Chinese hamster glutamine synthetase gene was generously provided by Dr. R.H. Wilson, University of Glasgow, Scotland. The work was supported in part by grants from NASA (NAG 2-100), NIH (HD 16956), and the Bressler and Chancellor's Funds of the University of Maryland. 


\section{References}

1. Koski CL, Rifenberick $\mathrm{OH}$, Max, SR 1974 Oxidative metabolism of skeletal muscle in steroid atrophy. Arch Neurol $31: 407$

2. Kelly FJ, McGrath JA, Goldspink DF, Cullen MJ 1986 A morphological/biochemical study on the actions of corticosteroids on rat skeletal muscle. Muscle Nerve 9:1

3. DuJovne CA, Azarnoff DL 1975 Clinical complications of corticosteroid therapy: a selected review. In: Azarnoff OL (ed) Steroid Therapy, W.B. Saunders, Philadel phia, p 27

4. Konagaya M, Bernard PA, Max SR 1986 Blockade of glucocorticoid receptor binding and inhibition of dexamethasone-induced muscle atrophy in the rat by RU38486, a potent and selective glucocorticoid antagonist. Endocrinology $119: 375$

5. Wool IG, Weinshelbaum EI 1960 Adrenal cortical hormone and incorporation of $\mathrm{c}^{14}$ from amino acid precursors into muscle protein. Am J Physiol 198:360

6. Shoji S, Pennington RJT 1977 The effect of cortisone on protein breakdown and synthesis in rat skeletal muscle. Mol. Cell Endocrinol $6: 159$

7. Rannels SR, Rannels DE, Pegg AE, Jefferson LS 1978 Glucocorticoid effects on peptide-chain initiation in skeletal muscle and heart. Am J Physiol 235:E்134

8. Rannels SR, Jefferson LS 1980 Effects of glucocorticoids on muscle protein turnover in perfused rat hemicorpus. Am $J$ Physiol $238: E 564$ 
9. Odedra BR, Millward DJ 1982 Effect of corticosterone treatment on muscle protein turnover in adrenalectomized rats and diabetic rats maintained on insul in. Biochem $\mathrm{J} 204: 663$

10. Odedra BR, Bates PC, Millward DJ 1983 Time course of the effect of catabolic doses of corticosterone on protein turnover in rat skeletal muscle and liver. Biochem J 214:617

11. Ballard FJ, Francis, GL 1983 Effects of anabolic agents on protein breakdown in L6 myoblasts. Biochem $J$ 210:243

12. Clark AF, Vignos PJ 1979 Experimental corticosteroid myopathy: Effect on myofibrillar ATPase activity and protein degradation. Muscle \& Nerve 2:265

13. Clark AF, Vignos PJ 1981 The role of proteases in experimental glucocorticoid myopathy. Muscle Nerve 4:219

14. Mayorke N, Pinson A, Mayer M 1979 Intracellular proteolysis in rat cardiac and skeletal muscle cells in culture. $\mathrm{J}$ Cell Physiol $98: 587$

15. McGrath JA and Goldspink DF 1982 Glucocorticoid action on protein synthesis and protein breakdown in isolated skeletal muscles. Biochem J 206:641

16. Millward DJ, Garlick PJ, Nnayelugo Do, Waterlow JC 1976 The relative importance of muscle protein synthesis and breakdown in the regulation of muscle mass. Biochem $J 156: 185$

17. Smith RJ, Larson S, Stred SE, Durschlag RP 1.984 Regulation of glutamine synthetase and glutaminase activities in cultured skel etal muscle cells. J Cell Physiol 120:197

18. King PA, Goldstein L, Newsholme EA 1983 Glutamine synthetase activity of muscle in acidosis. Biochem $J$ 216:523 
19. Max SR, Thomas JW, Banner C, Vitkovic L, Konagaya M, and Konagaya Y 1987 Glucocorticoid receptor-mediated induction of glutamine synthetase in skeletal muscle cells in vitro. Endocrinology, in press.

20. Tildon JT, Zielke HR 1986 Glutamine: An energy source for mammalian tissues. In: $E$ Kvamme (ed) Glutamine and Glutamate in Mammals, CRS Press, New York, in press

21. Goldberg AL, Chang TW 1978 Regulation and significance of amino acid metabolism in skeletal muscle. Fed Proc 37:2301

22. Rowe WB 1985 Glutamine synthetase from muscle. Methods Enzymol, Academic Press, New York, vol 113:199

23. Lowry OH, Rosebrough NS, Farr AL, Randall RJ 1951 Protein determination with the Folin phenol reagent. $J$ Biol Chem $193: ? 65$

24. Maniatis T, Fritsch EF, Sambrook J 1982 Molecular cloning. Cold Spring Harbor Laboratory p. 190

25. Chirgwin JM, Przybyla AE, MacDonald RJ, Rutter WJ 1979 Isolation of biologically active ribonucleic acid from sources enriched in ribonuclease. Biochem 18:5294

26. Rave N, Crkvenjakov R, Boedtker H 1979 Identification of procollagen mRNAs transferred to diazobenzylmethyl paper from formaldehyde agarose gels. Nucleic Acids Res 6:3559

27. Southern EM 1975 Detection of specific sequences among DNA fragments separated by gel electrophoresis. J Mol Biol $98: 503$

28. Melton DA, Krieg PA, Rebagliati MR, Maniatis T, Zinn K, Green MR 1984 Efficient in vivo synthesis of biologically active 
RNA and RNA hybridization probes from plasmids containing bacteriophage SP6 promotor. Nucleic Acids Res 12:7035

29. Sanders PG, Wilson RH 1984 Amplification and cloning of the Chinese hamster glutamine synthetase gene. EMBO J 3:65

30. Winer BJ 1962 Statistical Principles in Experimental Design, McGraw-Hill, New York, p 302

31. Snochowski M, Dahlberg E, Gustafsson $3 A^{\circ} 1980$ Characterization and quantification of the androgen and glucocorticoid receptors in cytosol from rat skeletal muscle. Eur J Biochem $111: 603$

32. Philibert D 1984 RU38486: An original, multifaceted antihomone in vivo. In: Agarwal MK (ed.) Adrenal Steroid Antagonism, Walter de Gruyter and Co., Berlin, p. 1 ,

33. Konagaya M, Konagaya $Y$, Max SR 1986 Evaluation of the endogenous glucocorticoid hypothesis of denervation atrophy. J. Neurol. Sci., in press

34. Kawai S, Nieman LK, Brandon DD, Peden GW, Loriaux DL, Chrousos GP 1986 Pharmacokinetic properties of the glucocorticoid and progesterone antagonist RU486 in man. Clin. Res. $34: 401 \mathrm{~A}$

35. Schreiber JF, Hsueh AJW 1979 Progesterone "receptor" in rat ovary. Endocrinology $105: 915$

36. Perrot-Applanat M, Rogeat F, Groyer-Picard MT, Mil grom E 1985 Immunocytochemical study of mammalian progesterone receptor using monoclonal antibodies. Endocrinology 116:1473

37. Mercier L, Miller PA, Simons SS jr 1986 Antiglucocorticoid steroids have increased agonist activity in those hepatoma 
cell lines that are more sensitive to glucocorticoids. J Steroid Biochem 25:11

38. Dionne FT, LeSage RL, Dubé JY, Tremblay RR 1979 Estrogen binding proteins in rat skeletal and perineal muscles: In vitro and in vivo studies. J Steroid Biochem 11:1073

39. Kunar S, Holmes E, Scully S, Birren BW, Wilson RH, DeVellis J 1986 The hormonal regulation of gene expression of glial markers: glutamine synthetase and glycerol phosphate dehydrogenase in primary cultures of rat brain and in C6 cell line. J Neurosci Res 16:251

40. Bhandari B, Burns DM, Hoffman RC, Miller RE 1986 Glutamine synthetase mRNA in cultured $3 T 3-L T$ adipocytes. Complexity, content and hormonal regulation. Mol Cell Endocrinol 47:49

41. Clark AF, DeMartino G, Wildenthal K 1986 Effects of glucocorticoid treatment on cardiac protein synthesis and degradation. Am J Physiol 250:C821-C827

42. Max SR, Silbergeld EK 1986 Skeletal muscle glucocorticoid receptor and glutamine synthetase activity in the wasting syndrome in rats treated with $2,3,7,8$-tetrachlorodibenzo-pdioxin. Toxicol Appl Pharmacol, in press

43. DuBois DC, Almon RR 1984 Glucocorticoid sites in skeletal muscle: adrenalectomy, maturation, fiber type, and sex. Am J Physiol $247: \mathrm{Cl18}$

44. Close RI 1972 Dynamic properties of mammalian skeletal muscles. Physiol Rev 52:129

45. Horber FF, Scheidegger JR, Grunig BE, Frey BJ 1985 Evidence that prednisone-induced myopathy is reversed by physical training. $\mathrm{J} C \mathrm{Cl}$ in Endocrinol Metab $61: 83$ 
46. Goldberg AL 1969 Protein turnover in skeletal muscle. II. Effects of denervation and cortisone on protein catabolism in skel etal muscle. J Biol Chem $244: 3223$

47. Goldberg AL, Tischler M, DeMartino GV, Griffin G 1986 Hormonal regulation of protein degradation and synthesis in skel etal muscle. Fed. Proc. $39: 31$

48. Millward DJ 1978 Enzyme and protein turnover during growth and development. Biochem. Soc. Trans. 6:494

49. Millward DJ, Garl ick PJ, Steward RJ, Nnanyel ugo DO, Waterl ow JC 1975 Skeletal muscle growth and protein turnover. Biochem J $150: 235$

50. Waterlow JC, Stephens JML 1968 The effect of low protein diets on the turnover rates of serum, liver and muscle proteins in the rat, measured by continuous infusion of L[ $\left.{ }^{14} \mathrm{C}\right]$ lysine. Clin Sci $35: 287$ 


\section{Figure Legends}

Figure 1: Time-course of the effect of dexamethasone (5 $\mathrm{mg} / \mathrm{kg}$ ) on glutamine. symthetase activity in rat soleus and plantaris muscles. Data are means \pm SEM of 6 determinations. Experimental procedures are described in the text. "Significantly different from control, $p<0.02$, plantaris, $p<0.005$, soleus. ${ }^{\star \star}$ Significantly different from day 1 control; $p<0.005$, plantaris, $p<0.01$, soleus. " ${ }^{* *}$ Significantly different from day 3 control, $p<0.005$, soleus and plantaris.

Figure 2: Effect of RU38486 on the dexamethasone-mediated increase in glutamine synthetase activity in rat plantaris muscle. Dexamethasone was injected s.c. at $5 \mathrm{mg} / \mathrm{kg}$. RU38486 was administered p.0. at $50 \mathrm{mg} / \mathrm{kg}$. Glutamine synthetase was assayed after 3 days of administration of dexamethasone $(5 \mathrm{mg} / \mathrm{kg})$ and RU38486 (50 mg/ $\mathrm{kg})$. Data are means \pm SEM of six determinations. Experimental procedures are described in the text. "Significantly different from control, $p<0.005$. " Significantly different from the dexamethasone group, $P<0.01$. CTL, control, DEX, dexamethasone.

Figure 3: Steroid hormone specificity of glutamine synthetase induction in rat plantaris muscles. Steroid hormones were injected at $5 \mathrm{mg} / \mathrm{kg}$ (s.c.). TA, triamcinolone acetonide; $E_{2}$ estradiol-17B ; P, progesterone; $T$, testosterone. Glutamine synthetase was assayed $24 \mathrm{~h}$ after a single injection of steroid hormone. Data are means \pm SEM of six determinations (except control, $n=16)$. Experimental procedures are described in the text. *Significantly different from control, $p<0.001$. 
Figure 4: Effect of dexamethasone (5 mg/kg, s.c.) on glutamine synthetase activity in heart, plantaris, and soleus muscles. Glutamine synthetase was assayed after 7 days of daily dexamethasone injections. " Significantly different from control, $p<0.05 ; \quad \quad{ }^{\star *}$ Significantly different from control, $p<0.001$.

Figure 5: Northern blot analysis of glutamine synthetase induction by dexamethasone ( $5 \mathrm{mg} / \mathrm{kg}$, s.c.) in plantaris muscle and heart after 5 daily injections. CtI, control; dex, dexamethasone. Equal $(2.5 \mu \mathrm{g})$ amounts of total cellular RNA were applied to the gel in each instance. Experimental procedures are described in the text. A section of an autoradiogram containing cellular RNA hybridized to a radiolabeled glutamine synthetase RNA probe $(3 \mathrm{~Kb})$ is shown. 


\section{Table 1}

Glutaminase Activity in Soleus and Plantaris

Muscl es of Dexamethasone-Treated Rats

\begin{tabular}{lcc} 
Treatment & $\begin{array}{c}\text { Soleus } \\
(\mathrm{nmols} / \mathrm{mg}\end{array}$ & $\begin{array}{c}\text { Plantaris } \\
\text { protein/h) }\end{array}$ \\
\hline & & \\
\hline vehicle & $76.40 \pm 13.39^{+}$ & $83.54 \pm 16.11$ \\
dexamethasone & $.53 .83 \pm 7.36^{*}$ & $76.67 \pm 16.9$ \\
\hline
\end{tabular}

Rats were injected with dexamethasone daily for 7 days, at a dose of $5 \mathrm{mg} / \mathrm{kg}$, s.c. 'Data are means $\pm \mathrm{SEM}, n=6$. "Significantly different from control, $p<0.005$. 

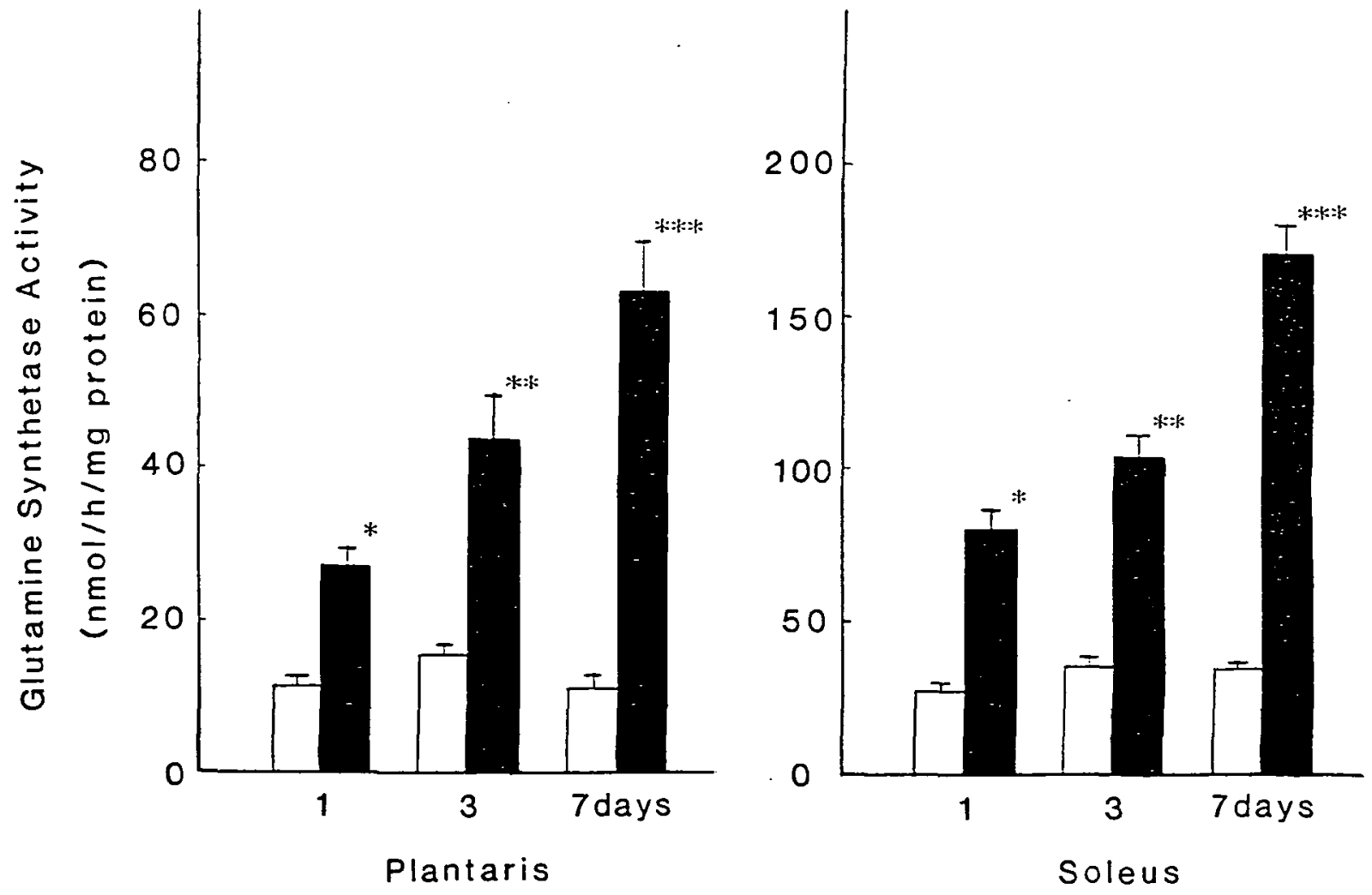


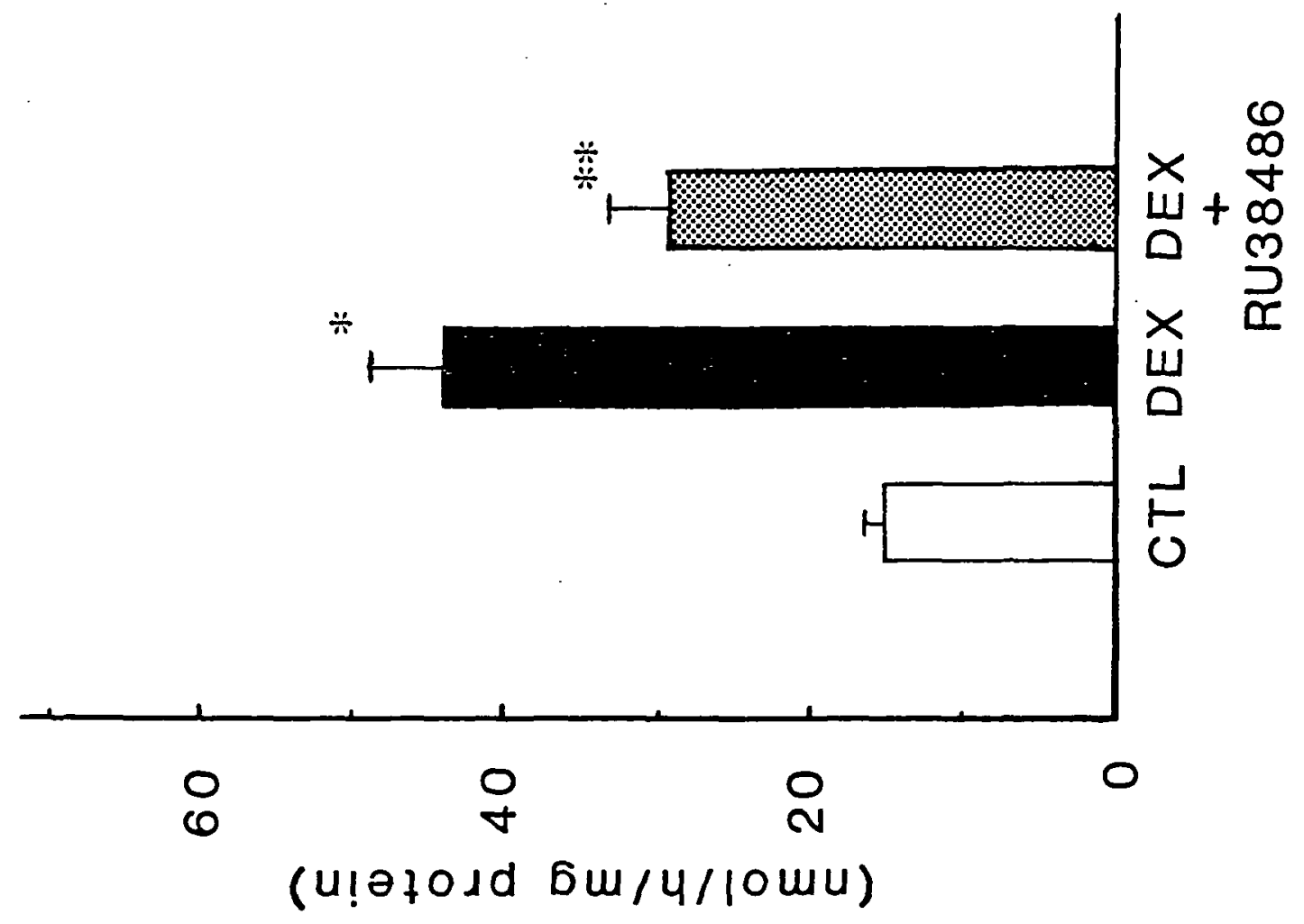

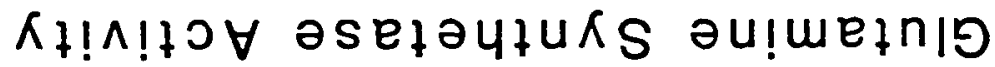




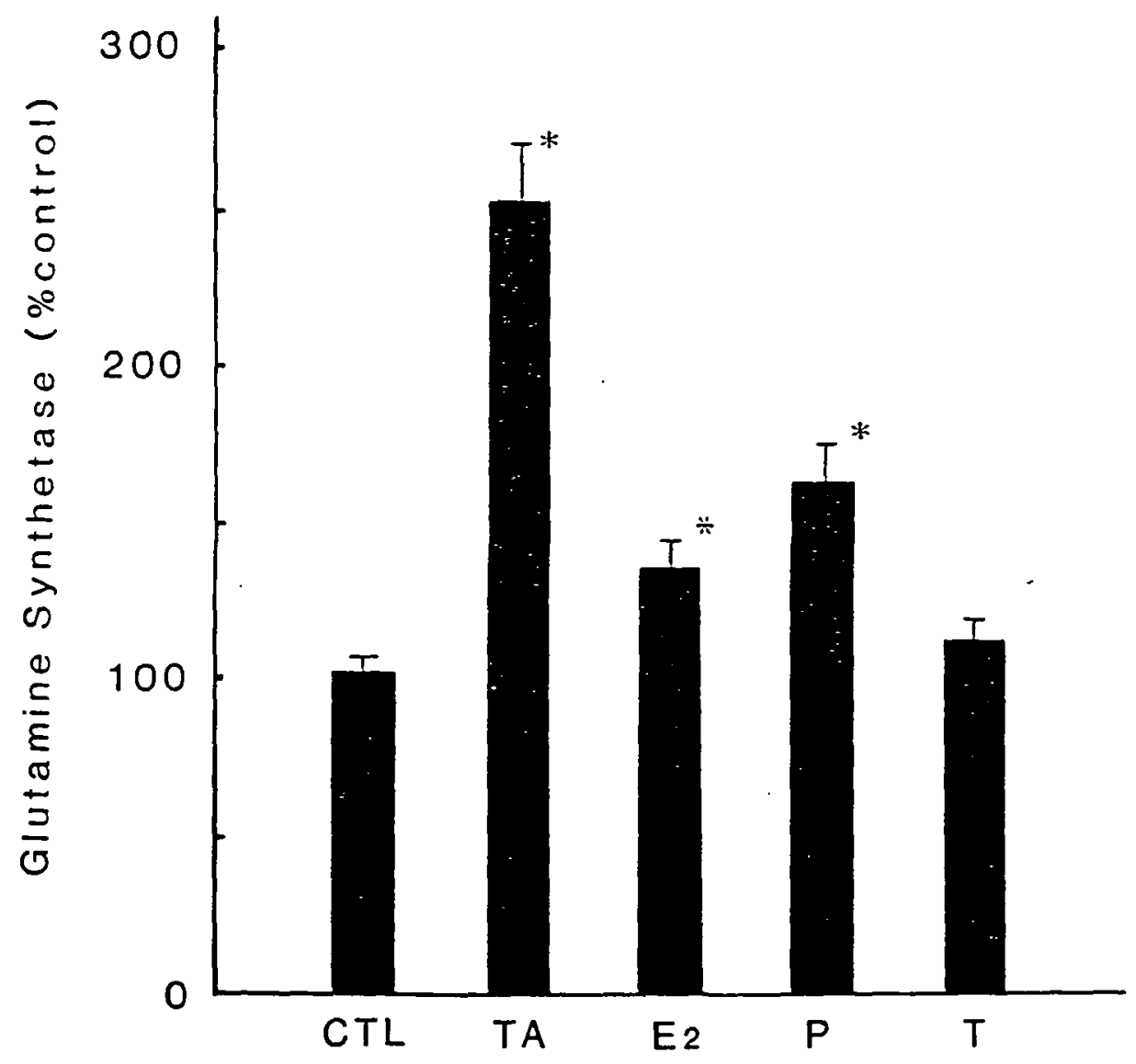




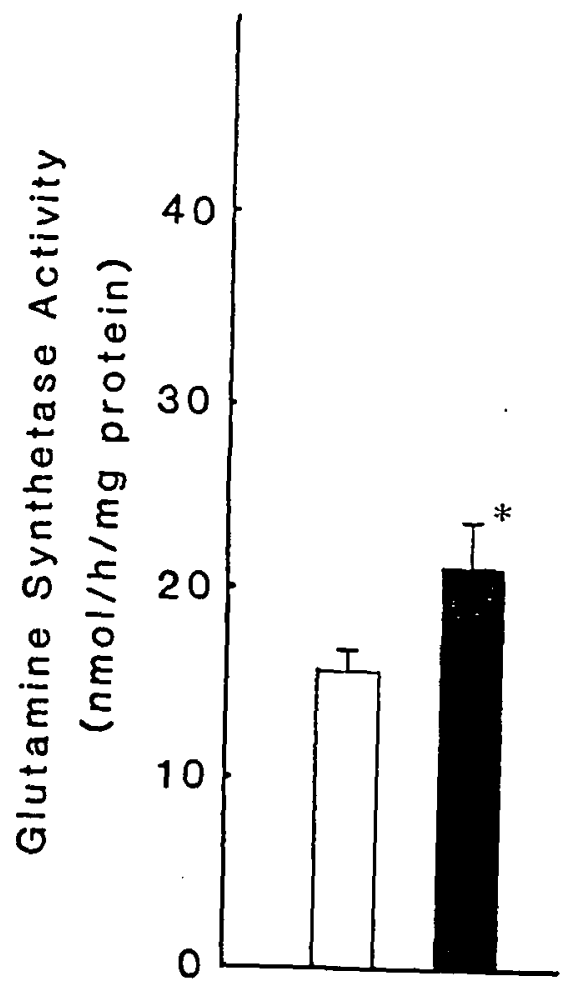

Heart

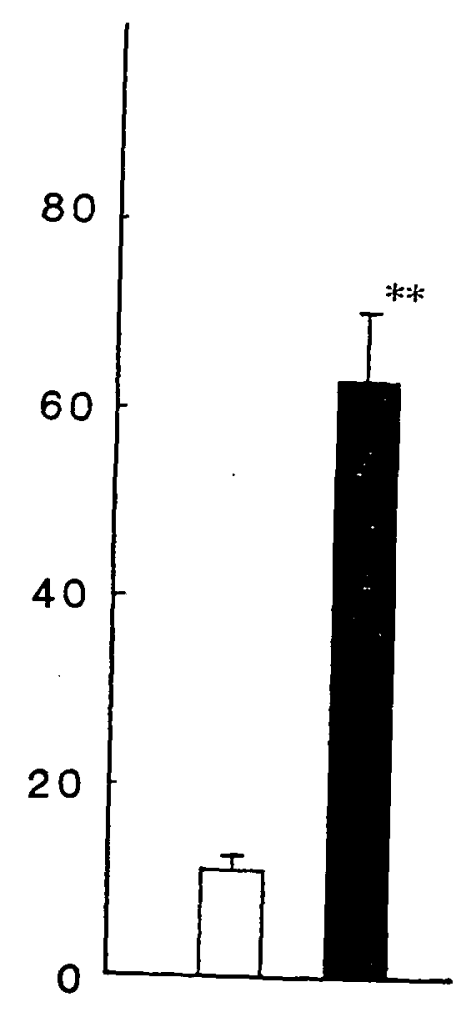

Plantaris

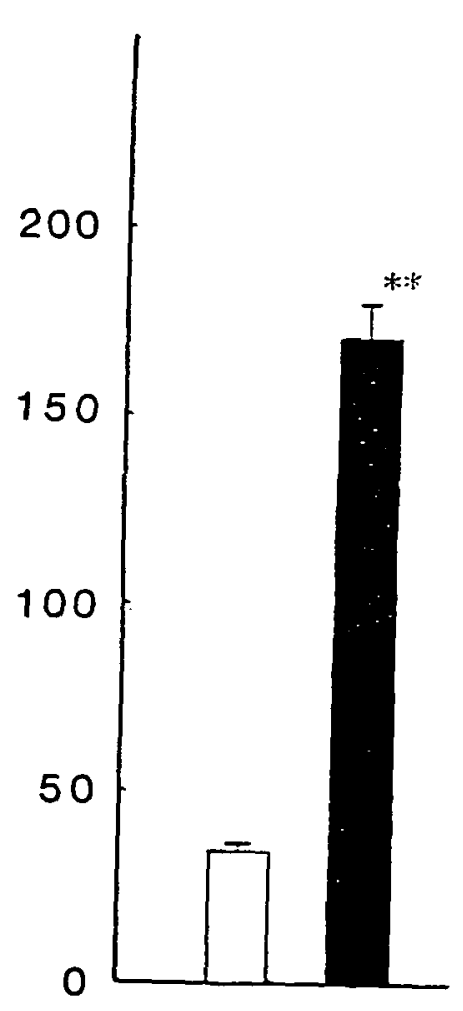

Soleus 